\title{
Study on Learning Freedom and Flexible Teaching Management
}

\author{
Zhang Xijun \\ Shijiazhuang Vocational Technology Institute, Shijiazhuang, China \\ ae65381226@.qq.com
}

Keywords: Learning Freedom; Flexible Teaching; Management Research

\begin{abstract}
Learning Freedom is the core concept of modern university education. Learning culture of freedom and creative talents there is an inherent association. Learn the students as the main liberal education, giving students freedom of choice, is to foster an innovative spirit, innovation and the ability to create high-quality talent rich soil. Learning achievement of freedom required to meet the appropriate conditions, which the students have a sense of responsibility and self-realization of the spirit of freedom of the internal conditions of learning, school teaching and flexible management of the implementation of flexible learning is to achieve the freedom of external protection.
\end{abstract}

\section{Introduction}

In the history of Western thought, the concept of freedom, with the generation of slavery generated, initially only a political concept. Late Greek Stoic began to put forward the issue of personal freedom, the free into the field of philosophy.

Terms of metaphysical or speculative level, to explore the free nature of the core issues of philosophy, explain theory thus caused is voluminous. Looking at the history of Western ideas, theories about freedom includes freedom theory, libertarians and free choice theory. On freedom advocated freedom is an external negative freedom from coercion, it behaves as a legal right in modern society; inherent similarities between the libertarian and freedom of choice theory, they understood Freedom is a positive freedom, mainly refers to the main body has a self-directed, self-selection and self dominate the requirements and capabilities. Master Sartre existentialism, human freedom is freedom of choice, people are in a lot of possibilities to choose and create their own nature, to determine their own future destiny. He believes that the nature and purpose of education is personal "self-generated" or "self-creation." Jaspers believes that basic education is a personal freedom of choice and the growth of students is the student's "naturally occurring" rather than a planned "created." Kant believed that freedom is self-determination, freedom that people are inherently self-determination and to act voluntarily, without outside coercion and restraint. Marx freedom based on objective practice, pointed out that labor is the source of human freedom and the means to achieve freedom.

Freedom is the freedom to learn theory in the extension and expansion of fields of study. For learning specific understanding of freedom, different scholars have different understanding. Berlin University Fichte pointed out that freedom is an important part of learning academic freedom. Freedom is that students learn the correct method under the guidance of professors with the professional learning to explore, doubt, do not agree, and freedom to criticize the authorities, have a choice of what teachers and learning, the right to participate in education management review of ....... This is the first time in the history of education, "learning freedom" of the content to make specific elaboration. Three Principles of the Humanist Thought practitioners out of universities, the first is the principle of academic freedom. Among them, the study is that students have the right to free any course of study, including the selection of subjects, freedom of choice and transfer of teachers. 


\section{Problems of the Freedom Learning}

Freedom of learning in ancient China, there bud. After the abolition of the imperial examination system in Late Qing Cai in 1917 with "inclusive doctrine" we have successfully reformed the North, so that a thousand years of suffering repression of academic freedom is still a lot of thought weight problems, mainly in the legal recognition of the freedom of learning is not clear traditional shackles and college training model of freedom of belief and lack of learning to enjoy the freedom of a narrow range of learning and other aspects.

German university is the birthplace of the modern study of free thought. Learning freedom is protected by law in Germany. While Chapter 2 of our Constitution also provides 47: People's Republic of China citizens have the freedom of scientific research, literary and artistic creation and other cultural activities. But the direct guidance of Higher Education "Higher People's Republic of China Law" does not provide for the right of students to learn freedom. Visible, China's laws on freedom of students is not explicitly recognized. There is no legal basis, but did not form the traditional schools, colleges and universities so that students learn to enjoy our freedom are very limited.

Learning freedom is in the implementation of our colleges and universities facing such difficulties. The impact of China's long feudal vestiges of higher education, examination-oriented education has not been hard to say education model and its corresponding impact on the traditional civil service examinations. Student learning is firmly bound to the limited number of courses, learning as a tool to cope with exams, student free space difficult. Second, it is the long-term impact of the planned system. Under this system, the colleges and universities according to their professional enrollment, according to a unified plan to train teaching, students after graduation as planned allocation. Due to lack of historical tradition, the concept of freedom of learning and conflict with decades of academic standards, and thus, in the traditional training model no fundamental reforms, students cannot really enjoy learning free space.

Students are free to learn beneficiaries, they learn to deal with this freedom there is a strong demand. However, our students learn not only the lack of freedom of belief that the rights should have been entitled to a lack of ability to control. Flexible teaching reform in the existing exhibit of students does not believe their ability to choose, do not have the ability to choose the problem is very prominent. There are objective and subjective reasons for this aspect. First, enter the university students are mostly young people aged around 20 (although existing reforms relaxed the age limit for enrollment in higher education, but students still account for the vast majority of this age group), they have not yet fully mature physically and mentally, their life , values are not finalized, they also lack the ability to self-selection and design. Secondly, due to the impact of exam-oriented education, students learn knowledge and awareness neither freedom, and never had the opportunity to experience choice. Thus, faced with learning freedom, students choose either afraid or do not know how to choose and select what should be done. It is also because the students are lack of learning freedom of the faith, so, the Higher Education Innovation is difficult to hear the call for freedom to learn from them.

Learning Freedom not only has a very rich content, but also the range of its influence and radiation, including almost all aspects of running a university. But students in Chinese universities already exist in the reform of freedom enjoyed learning a narrow range of issues in particular. Currently, elective courses in Chinese universities (including elective courses and electives) accounted for only 10-30\% of all courses, low proportion. And due to resource constraints limit enrollment arranged on behalf of the majority to become school enrollment, which disguised a required course, students have a choice at all difficult. It is difficult to be guaranteed in any elective from the quantity and quality. A small range of elective like this, not to mention picking a major, choose a school, chose to study time. Thus, freedom of College students not only in the breadth of choice is small, but select privileges within this range is not large, which is China's universities to study narrow and restrict the freedom of understanding the objective conditions are not divided open. 


\section{Flexible Teaching Management is the Inevitable Choice of the Free Education Practice}

Freedom of belief only as a learning practice in higher education will "bear fruit." Therefore, in practice to protect the freedom of learning has become an important mission of colleges and universities. This is a systematic project, which involves higher education ideology, personnel training programs, teaching facilities, teacher quality and other aspects, Flexible teaching management reform is an important part. Flexible teaching management is a new concept of educational administration, it focuses on selection, care about people --- focus on human needs, aspirations and feelings, concerns people's self-awareness.

Learning freedom calls for flexible teaching management. Learning requires colleges and universities to give students the freedom to choose schools, professional freedom, choose the professional, inter-professional or inter-institution free courses, and so on. Decide what time to learn and how to learn the freedom of universities offer courses proposed thoughtful adaptation of the requirements, the university should meet the learning needs of different courses, tolerance and adaptation to the students' different learning styles. It's all for Higher traditional rigid teaching management challenges. Under the rigid teaching management, students receive professional and school choice, a unified compulsory and elective course, and the time is fixed, classrooms fixed, fixed teachers, learning ways than a single. Students' academic decide the merits of a unified by the papers, the students difficult to form their own ideas, they cannot make public its personality. The study calls for freedom are precisely the difference and choose to respect the rights of students to meet students' diverse needs new management model. Flexible teaching management in its attention to individual students need to learn to adapt to freedom.

Flexible teaching management is the guarantee of freedom learning. Flexible teaching management can learn free from ideological, institutional and technical support. First of all, freedom is the core of learning options, including the school, curriculum, teachers, teaching place, learning time and other select educational resources. Flexible teaching management allows students from any stage into the school until graduation to make their own choices. For example, allowing students into the school after a period of time for professional learning and secondary choice of schools, allowing students to graduate early to work or continue their studies, allowing students to choose the curriculum and teachers, even allowing students suspended midway. University students throughout the learning process and select everywhere and at all times. Secondly, Flexible teaching management to learn the freedom to provide institutional guarantee. In the middle level of the system, on the order of ideas, the concept is embodied; Kai specific measures under the guidance of the work. For all choose to graduate students enrolled, Flexible teaching management are corresponding. Credit changed the traditional school system of rigid, so that students in the choice of years of study can make arrangements according to their actual situation. Elective system, minor academic but also gives students in learning and personal development path of knowledge can be designed according to their wishes. Development of computer network and multimedia technology makes Flexible teaching management received technical support, and then to provide the conditions for the realization of freedom of learning.

Flexible teaching management needs to further improve and expand students' freedom. Since history is not long, lack of experience, our colleges and universities to implement Flexible teaching management reform a lot of the problems. The current main task is to actively explore the theory and practice, to further improve the elasticity of teaching management, and effectively protect the right to freedom of students.

Reform of the problems in this stage most of the reason is because the theory of inadequate preparation. Study Flexible teaching management theorists is not deep enough; leadership universities, teachers in thinking there is no clear understanding, resulting in a lack of confidence appears to reform; the actual reform efforts due to lack of theoretical support, direction unknown. Therefore, the key to improve the elasticity of teaching management reform is sound theory. Higher education should not only theoretical workers worked, universities all concerned should learn from 
the experience at home and abroad, combined with their own actual theoretical understanding Flexible teaching management, and to contribute to its sound theory.

\section{Conclusion}

Currently, the understanding of freedom of learning in Chinese Universities also seemed narrow, limited to the students' choice of courses, that is, the right to choose in this range is also extremely limited. In order to effectively change this situation, the university should emancipate our minds, boldly explore and gradually establish and perfect a set of Flexible teaching management system to ensure that teaching and training work openness, selectivity, diversity and adaptability, but also the freedom of students to learn, enables students to autonomy, freedom, self-discipline to learn to make higher education services to students "free and full development."

\section{References}

[1] Don Ethridge. Research on methodolgy in applied economics. Iowa State University Press, Ames, Iowa, USA.

[2] John, Martin. Organizational Behavior, International Thomson Publishing Company, UK.

[3] B. N. Ma, The Legal Problems of Education System, J. Modern Law. 44 (2010) 146-147.

[4] H. X. Zeng, The Risk Analysis of Private Education Market, J. Legal Science. 18(2005) 55-57. 